\title{
A review of the evidence for occupational exposure risks to novel anticancer agents - a focus on monoclonal antibodies
}

J King, M Alexander, J Byrne, K MacMillan, A Mollo, S Kirsa, M Green

Julie King, B. Pharm, Pharmacy Department, Western Health, Melbourne, Australia

Marliese Alexander, B.Pharm, Grad Cert Pharm Prac, MPH, Pharmacy Department Peter MacCallum Cancer Centre, Melbourne, Australia

Jenny Byrne, Western \& Central Melbourne Integrated Cancer Service, Melbourne, Australia

Kent MacMillan, B. Pharm, M.Sc, Pharmacy Department, Western Health, Melbourne, Australia

Adele Mollo, RN, Operations Manager, Western Health, Melbourne, Australia

Sue Kirsa, B.Pharm, Grad Dip Hosp Pharm, FSHP, Pharmacy Department Peter MacCallum Cancer

Centre, Melbourne, Australia

Michael Green, MBBS FRACP FACP, Department of Cancer Services, Western Health, Melbourne, Australia

\section{Corresponding Author:}

Conflicts of Interest:

Funding:

Keywords:

Abstract words:

Words:

Tables:

Figures:

References:
Marliese Alexander

Department of Cancer Medicine, Peter MacCallum Cancer Centre, Melbourne, Australia

Marliese.Alexander@petermac.org

p 6139656 3583, f 61396561405

Locked Bag 1 A'Beckett Street, Victoria 8006 Australia

The following listed authors are consultants or advisory committee members or receive honoraria, fees for service, or travel assistance (independent of research-related meetings) from; or have research or other associations with the organizations listed: Michael Green Roche, Sandoz; Sue Kirsa - Roche, Sandoz, Amgen, Orion, Perigo, Novartis.

This project was funded by Western and Central Melbourne Integrated Cancer Service (WCMICS) as part of a project commissioned to develop safe handling guidelines for monoclonal antibodies.

Cancer, occupational exposure, guidelines, monoclonal antibodies

243

2812

3

0

114 


\section{A review of the evidence for occupational exposure risks to novel anticancer agents - a focus on monoclonal antibodies}

Introduction: Evidence of occupational exposure risks to novel anticancer agents is limited and yet to be formally evaluated from the Australian healthcare perspective.

Methods: From March to September 2013 medical data-bases, organizational policies, drug monographs and the World Wide Web were searched for evidence relating to occupational exposure to monoclonal antibodies (MABs), fusion proteins (FP), gene therapies, and other unclassified novel anticancer agents.

Results: Australian legislation, national and international guidelines and drug company information excluded novel agents or provided inconsistent risk assessments and safe handling recommendations. MAB guidelines reported conflicting information and were often divergent with available evidence and pharmacologic rationale demonstrating minimal internalisation ability and occupational exposure risk. Despite similar physiochemical, pharmacologic and internalisation properties to MABs, FPs were included in only a minority of guidelines. Clinical directives for the safe handling of gene therapies and live vaccines were limited; where available focusing on prevention against exposure and cross-contamination. Although mechanistically different, novel small molecule agents (proteasome Inhibitors), possess similar physiochemical and internalisation properties to traditional cytotoxic agents warranting cytotoxic classification and handling.

Conclusion: Novel agents are rapidly emerging into clinical practice and healthcare personnel have few resources to evaluate risk and provide safety recommendations. Novel agents possess differing physical, molecular and pharmacological profiles compared to traditional cytotoxic anticancer agents. Evaluation of occupational exposure risk should consider both toxicity and internalisation. Evidence-based guidance able to direct safe handling practices for novel anticancer agents across a variety of clinical settings is urgently required. 


\section{Introduction:}

Novel anticancer agents are in rapid development with many already in routine clinical use and others likely to emerge into clinical oncology and haematology practice in the near future. For the purposes of this review, novel anticancer agents were defined as agents used in prevention, treatment or supportive care of cancer patients that were not alkylating agents, anti-metabolites, anti-microtubule agents, topoisomerase inhibitors or cytotoxic antibiotics (anthracyclines). Relevant classes of anticancer agents therefore included monoclonal antibodies (MABs), fusion proteins (FP), gene therapies, and other unclassified novel anticancer agents such as proteasome inhibitors and vaccines. These novel agents often possess different physiochemical, pharmaceutical and pharmacologic properties compared to traditional agents. They often are not truly cytotoxic, do not clearly fulfil hazardous substance criteria nor have defined occupational occupational exposure limits, ${ }^{1,2}$ and do not meet chemical labeling classifications. ${ }^{3,4}$ This comprehensive literature review aimed to identify and evaluate available literature relating to occupational exposure risks and current practice standards for novel anticancer agents, focusing on the most commonly utilised and most widely available class of MABs.

\section{Methods:}

A comprehensive literature review was undertaken between March and September 2013 to identify evidence relating to occupational exposure to MABs, FPs, gene therapies, and other unclassified novel anticancer agents. The literature was evaluated for current regulations and practice standards, and occupational exposure risks. Occupational exposure risk evaluation included assessment of toxicity (therapeutic and occupational exposure levels), internalisation potential (including animal studies and theoretical pharmacologic mechanisms), as well as manufacturing and operational considerations that may impact on occupational exposure or product integrity. Expecting a scarcity of data no exclusion criteria or search limitations were applied. Following an initial broad search for all classes defined here as novel agents the search was narrowed to MABs, the most commonly used and widely available class with the greatest impact for healthcare services.

Medical data-bases searched included Medline (OVID), Cumulative Index to Nursing and Allied Health Literature (CINAHL), Wiley Interscience, Embase, Pubmed and the Cochrane Library. Searches were conducted using both Medical Subject Heading (MeSH) terms and text words. The MeSH term monoclonal antibodies, was selected and initially exploded to include all subheadings. The search was then refined by combining the following text words: administration, exposure, guidelines, 
handling, metabolism, pharmacokinetics, pharmacokinetics, pharmacology, physiology, poisoning, or safety. The reference lists of relevant papers were also searched.

Organizational policy review included Australian government regulations, standards and codes of practice, Australian and international professional association guidelines (pharmacy, medical and nursing) and publically available institutional guidelines. Individual drug evaluations (product information (PI) and material safety data sheets (MSDS)) were undertaken for a subset of novel agents with the intention of describing a representative sample of novel anticancer molecules. Selection was based on agents which are commonly used in Australian oncology and haematology settings and which are reflective of the range of therapeutic drug classifications, parenteral administration routes and preparation techniques. Drug evaluations were undertaken for aflibercept, alemtuzumab, bacillus calmette-guerin (BCG), bevacizumab, bortezomib, brentuximabvedotin, cetuximab, denosumab, ipilimumab, ofatumumab, panitumumab, rituximab, trastuzumab and trastuzumab-emtansine. The World Wide Web (via Google) was searched for related unpublished material.

\section{Results:}

Using the described methodology only a limited number of relevant scientific papers were identified, providing a low level of evidence from which to evaluate occupational health and safety risks (National Health and Medical Research Council (NHRMC) levels III-IV or non-gradable (animal and in vitro pharmacologic studies)). Risk evaluations of stated novel agents were untaken considering cytotoxicity, organ toxicity at low doses, immunogenicity, teratogenicity, mutagenicity, carcinogenicity, molecular weight (MW), sterility and stability, and operational factors (required number of manufacturing steps and administration route), table 1. Evaluation of Australian legislation, professional organisation guidelines and practice standards, and independently published guidelines found exclusions, contradictions and variable practice recommendations for the safe handling of novel agents, table 2. Similar results were found within MAB specific guidelines, table 3.

\section{Unclassified novel anticancer agents}

Within this category of novel agents are diverse anticancer therapies (in action, morphology and pharmacology) that are otherwise uncategorized, including proteasome inhibitors and live vaccines. Proteasome Inhibitors are small molecule chemical entities developed from peptide aldehydes. ${ }^{5}$ Bortezomib (Food and Drug Administration (FDA) and Therapeutic Goods Administration (TGA) 
approved) and carfilzomib (FDA approved) are currently approved for use in the treatment of multiple-myeloma with several other proteasome inhibitors under clinical investigation. ${ }^{6,} 7$ Bortezomib, a dipeptide molecule (boronic acid analogue), was the first anti-cancer agent to target cancer cells via this mechanism and is licensed for both subcutaneous and intravenous administration. ${ }^{8}$ Bortezomib exhibits direct cytotoxic activity by induction of proteolysis and distribution of signally cascades and homeostatic mechanisms. Classified as a cytotoxic agent, ${ }^{9}$ bortezomib (and other proteasome inhibitors) require preparation and handling precautions as for other injectable cytotoxics. ${ }^{10}$ Bacillus Calmette-Guerin (BCG) is live attenuated Mycobacterium bovis (tuberculosis) and is used as an immunostimulant in the treatment of bladder cancer. BCG has been in clinical use for over thirty years and works by producing localised inflammatory reactions resulting in elimination or reduction of superficial tumour lesions of the bladder. ${ }^{11}$ Due to its biological nature, BCG is classified both as a hazardous substance and bio-hazardous material with all equipment, supplies, and receptacles in contact with BCG to be handled and disposed of as for biohazard material. $^{12}$

\section{Gene Therapies}

Currently no gene therapy agent is approved for clinical use anywhere in the world. However, more than 1800 gene therapy clinical trials in more than 30 different countries have been approved, completed or are ongoing with almost $65 \%$ within the oncology setting. ${ }^{13}$ Gene therapy relies on the delivery of the therapeutic gene to the target site, achieved through the use of genetically modified organisms (GMOs) such as viruses. ${ }^{14}$ In Australia, the Gene Technology Act 2000 regulates the use and handling of live and viable GMOs, with stated objective to protect people and the environment and to identify and manage risks associated with gene technology. ${ }^{15}$ In Australia, human gene therapy (introducing a GMO into a human) requires licence from the Regulator. Australian pharmacy practice standards (Society of Hospital Pharmacists Australia (SHPA)) recommend that gene therapies be handled in dedicated negative pressure clean areas to prevent healthcare workers from yet undisclosed risks. ${ }^{16}$ Practice standards from the International Society of Oncology Pharmacy Practitioners (ISOPP) stipulate that separate ventilation tools and cabinets be used for the preparation of gene therapies (and other biological products) so as to minimise crosscontamination. ${ }^{17}$ According to the United Kingdom Health and Safety Executive (HSE), the majority of gene therapies in clinical research fall into the lowest occupational hazard categories (1 or 2 ) and that preparation (basic reconstitution or dilution) may occur in pharmacy manufacturing units, or in some circumstances at the bedside. ${ }^{18}$ Class 1 agents do not require the use of microbiological safety cabinets for operator safety, rather the HSE recommend this as standard practice to safeguard 
product purity. HSE recommends actions to avoid cross-contamination including cabinet decontamination and disinfection and time lapse between cabinet use for different organisms.

\section{Fusion Proteins}

Derived from fusion genes, which are themselves created by joining parts of two different genes, FPs differ from the chemical structure of traditional anticancer agents. They may occur naturally in the body by transfer of deoxyribonucleic acid (DNA) between chromosomes or may be created in the laboratory by the fusion of the crystalline fragment $(F c)$ of human Immunoglobulin $G$ (IgG-1) (to provide sufficient biologic half-life for clinical application) with a natural human soluble receptor or ligand of a target molecule. ${ }^{19}$ Occupational exposure risks associated with FP are unclear and specific safe handling recommendations were largely lacking within broader hazardous substance guidelines and regulations, table 2 . Where FP were included, recommendations aligned with those for MABs based on structural similarities (large proteinaceous molecules). ${ }^{20,21}$ MSDS for FPs available in Australia (etanercept and abatacept; non-oncology indications) recommend exposure controls similar to those required for cytotoxic agents; safety glasses, gloves, lab coat or over garment, exhaust ventilation or containment and respirator masks. ${ }^{22,}{ }^{23} \mathrm{FPs}$ can be conjugated to other agents (antibodies or cytotoxics), ${ }^{24}$ with handling recommendations based on the most hazardous component.

\section{Monoclonal antibodies}

MABs have been absent in existing Australian occupational exposure and safe handling guidelines, tables 2 and 3, with the exception of a recently published position statement from the Cancer Pharmacists Group (CPG) of the Clinical Oncological Society of Australia (COSA). ${ }^{21}$ At the time of this review fourteen MABs were approved by the FDA and ten by the TGA, for use in the treatment of solid and haematological malignancies. ${ }^{6,7}$ Additionally, MABs with non-oncology indications are used off-licence in cancer therapies and more than one-hundred new MABs are currently in development or undergoing regulatory review. ${ }^{25}$ Derived from monoclonal cell lines, MABs comprise of an antigen-binding fragment ( $\mathrm{Fab}$ ) and crystalline fragment $(\mathrm{Fc})$ which facilitate engagement of tumour antigens and binding to receptor sites. cell. ${ }^{26}$ As protein rather than chemical entities, conventional toxicity tests are not necessarily appropriate or achievable. According to the International Conference on Harmonisation of Technical Requirements for Registration of Pharmaceuticals for Human Use (ICH) guidelines (adopted by the Australian Therapeutic Goods Association (TGA), American Food and Drug Administration (FDA) and the European Medicines Agency (EMA); as pharmaceutical products derived from biotechnology there is no requirement for MABs to be evaluated for either carcinogenicity or genotoxicity. ${ }^{27}$ 


\section{Monoclonal antibodies - external toxicity risk}

No reports of MAB-induced healthcare personnel skin irritation or allergic reaction were identified. Contact allergies may be triggered by excipients such as tensides (Polysorbate (also known as Tween 20 \& Tween 80)) which are found in numerous pharmaceutical formulations. ${ }^{28}$ These excipients are utilised in MAB formulations to prevent surface adsorption, stabilise against protein aggregation and retain biologic activity. ${ }^{29}$

\section{Monoclonal antibodies - internal toxicity risk}

Toxicity profiles of evaluated MABs are summarised in table 1. Listed toxicities are reported from therapeutic administration with no reported toxicities from occupational exposure. Although no direct mechanism for cytotoxicity, a molecular study demonstrated that low concentrations $(5 \mathrm{mg} / \mathrm{kg})$ of investigational therapeutic epidermal growth factor (EGFR) specific MAB reduced tumour volume via antibody-dependent cellular cytotoxicity (ADCC) induction of EGFR signalling inhibition. ${ }^{30}$ Additionally, MAB-polyethylene glycol (PEG) conjugate, Certolizumab-Pegol, has demonstrated cytotoxic activity by direct induction of death in nonapoptotic cells of transmembrane TNF- $\alpha$ expressing cells. ${ }^{31}$

Several MAB handling guidelines extrapolate toxicity profiles from therapeutic administration to the occupational exposure setting. ${ }^{32-34}$ Bioavailability is the major determinant of internal exposure, ${ }^{35}$ with the first and rate limiting step being absorption; the uptake of the substance into the body systems. Possible routes of absorption following occupational exposure are direct contact (dermal or mucosal absorption), inhalation, or accidental ingestion or injection.

Dermal and inhalation routes are the most likely means of exposure in health care facilities. Quantitative structure-permeability relationships (QSPRs) indicate that molecular size (smaller molecular size associated with increasing skin permeation) and hydrophobicity (increasing hydrophobicity associated with increasing skin permeation) are the main determinants of transdermal penetration. ${ }^{36}$ The molecular size of drugs for transdermal delivery (and of contact allergens) is typically less than 500 Dalton. ${ }^{37} \mathrm{MABs}$ are hydrophilic molecules, ${ }^{38}$ with molecular size typically in excess of 140 Kilo Dalton, table1. Published guidelines and position statements agree that dermal absorption of MABs is unlikely, ${ }^{21}, 32,39,40$ but still recommend wearing gloves, table 3. Whether gloves are recommended for occupational risk minimisation or for the protection of product integrity is not clearly stated. 
Biophysical and functional evaluation demonstrated that MABs are able to withstand the constraints of physical agitation required for aerosolisation and retain structural integrity and activity. ${ }^{41,42}$ Inhalation of aerosolised MAB (cetuximab) in genetically modified (Babl/c nude) mice resulted in durable accumulation in the lungs with limited and slow passage into systemic circulation. ${ }^{41} \mathrm{An}$ unpublished animal study testing a variety of $M A B$ inhalation and tracheal instillations in more than one animal species and with more than one MAB, found that MABs with MW between 120-200 Kilo Dalton, expected absorption was less than $5 \%{ }^{43}$ Published guidelines and position statements considered inhalation to be the most likely route of occupational exposure. ${ }^{32-34}$ All evaluated guidelines that included safe handling recommendations recommended the use of protective masks during preparation and handling, table 3 . The ability to generate liquid aerosols capable of reaching the alveoli during routine occupational conditions is debatable ${ }^{40}$ and one guideline recommended the use of protective masks for powered formulations only. ${ }^{39}$

Vaginal mucosal drug delivery of MABs achieved high concentration in vaginal secretions (approximately 100 times lower in blood and other tissues) for up to 30 days after insertion of polymer vaginal rings (designed to provide continuous antibody delivery) in mice. ${ }^{44}$ Porcine nasal mucosal MAB delivery (bevacizumab) achieved local but not systemic drug availability; $83 \%$ of original drug dose recovered within the nasal mucosa; $53 \%$ on the surface, $19 \%$ into and $11 \%$ through the mucosa. ${ }^{45}$ Negligible systemic bioavailability was concluded in the absence of noticeable histological effects. Murine nasal mucosal MAB delivery (MAB MW 160 Kilo Dalton) resulted in rapid increase in IgA and IgG antibody levels within lung lavage without transfer into bile and undetectable serum levels. ${ }^{46}$ Ocular mucosal application of liposome-incorporated and free MAB (murine derived $\operatorname{lgG1}$ anti CD4) to rat cornea (9 micrograms 5 times daily for 10 days) demonstrated significantly reduced rates of corneal transplant rejection (targeted activity). ${ }^{47}$ Liposomal MAB, free MAB and untreated rats experienced corneal rejection rates of $25 \%, 58 \%$ and $63 \%$ respectively. Negligible systemic bioavailability was concluded in the absence of systemic depletion of targeted lymphocytes (flow cytometry analysis). Masks and protective eyewear afford protection against mucosal (nasal and ocular) absorption; recommendations varied within evaluated guidelines, table 3 .

Pharmacological rationale dictates that oral ingestion of MABs will result in denaturation and inaction of the protein molecule by gastric acids and enzymes. ${ }^{48-50}$ Animal ${ }^{51}$ and human studies ${ }^{52,53}$ have demonstrated that MABs can survive gastric conditions and exert systemic activity. A comparison of oral versus intravenous MAB (CD3-specific antibody) administered to mice revealed 
equal effectiveness against autoimmune encephalomyelitis. ${ }^{51}$ The study demonstrated that the Fc portion of the antibody was not required for activity with similar effects observed with oral Fab fragments alone. A denaturation study demonstrated that Fab fragments are more tolerant of acid environments compared to Fc fragments; Fc denaturation occurring at pH3.5 vs. ph2.0 for Fab. ${ }^{54}$ Human and in vitro (using human gastric aspirates) studies show that despite some denaturation, MABs can survive gastric conditions to retain biological activity. ${ }^{52,53}$ The single human study included 20 healthy volunteers (10 randomised to receive MAB) infected with E. coli H10407; all volunteers recorded infective stool samples. ${ }^{53}$ Systemic activity was observed from the orally administered MAB (directed against enterotoxigenic E. coli) which was co-administered with an antacid to create favourable conditions (to prevent denaturation). Biologic activity was concluded based on clinical outcomes; 0/10 patients receiving MAB reported diarrhoea compared to $9 / 10$ controls, $p<0.0001$.

\section{Manufacturing and Operational Considerations}

Surface and airborne drug contamination is a recognised occupational hazard for cytotoxic anticancer agents. ${ }^{55-57}$ Similar studies reporting MAB contamination were not identified. The significance of MAB contamination (if present) is unknown. Cytotoxic contamination in Australian hospital pharmacy departments has been demonstrated a variety of surfaces within manufacturing units including inside cabinets, on floors and on checking benches. ${ }^{55}$ Gaseous drug (cyclophosphamide) has been detected in 7 of 15 locations tested for airborne contaminants. ${ }^{56}$ Personal protective equipment (PPE) has been tested for protection against surface, airborne and direct contact with cytotoxic anticancer agents; similar studies for MABs were not identified. Across three Dutch hospitals the use of protective gloves ( $2 \times$ latex surgical gloves) reduced the amount of worker exposure (detectable drug in hand wash samples); detectable drug (cyclophosphamide) on worker hands was 0.002 $\mathrm{ng} / \mathrm{cm}^{2} / \mathrm{min}$ versus $0.45 \mathrm{ng} / \mathrm{cm}^{2} / \mathrm{min}(\mathrm{p}=0.009)$ with and without gloves. ${ }^{57}$ Recommendations for the selection, use, maintenance and performance testing of respiratory protection equipment against potentially harmful atmospheric exposures are defined in Australian and New Zealand Standards AS/NZS 1715:2009 and AS/NZS 1716:2012. ${ }^{58,59}$ ISOPP standards stipulate a P2 or P3 mask for protection against cytotoxic agents, ${ }^{17}$ whilst SHPA refer to aforementioned standards and the requirement for protection against aerosols as well as liquid spills. ${ }^{10}$ Protective eyewear with side shields protects from splashes as the entire periphery of the goggle is in contact with the face, ${ }^{60}$ and are recommended for handling of cytotoxic agents. ${ }^{10,17}$ Gowns with polyethylene or vinyl coating have proved to be superior to polypropylene homopolymer gowns which failed splash testing (allowing penetration of both water and non-water based cytotoxic agents). ${ }^{61}$ Closed System Drug Transfer Devices (CSDTDs) offer protection to product and worker. Evaluation of five commercial 
brands found differing levels of contamination among the tested devices. ${ }^{62}$ Only one product (PhaSeal ${ }^{\oplus}$ ) met the NIOSH and ISOPP definition of a CSDTD; closed system (in reference to both microbiological and chemical contamination) and drug containment throughout all preparation and administration manipulations. ${ }^{1,17}$ The efficacy of Phaseal ${ }^{\circledR}$ has been demonstrated in other Australian and international studies. ${ }^{63-67}$

Some safe handling guidelines include consideration of drug complexity (dose calculation or reconstitution manipulation) when evaluating occupational exposure risk. ${ }^{20,21,33,34}$ Lacking demonstrative studies, the implication is that complex or numerous manipulations may increase error and/or exposure risks to healthcare personnel (and contamination risks to the product). MABs vary in complexity from ready-to-use formulations to requiring more than 20 manipulations, table 1. Interruptions during medication preparation in ward settings (conceivably during MAB reconstitution) are reported at a rate of up to 5.2 interruptions per hour. ${ }^{68}$ Evaluation of whether interruptions correlate with preparation error, spillage or exposure were not reported in this study nor identified in other studies. There is weak evidence of a correlation between interruptions and medication administration error. ${ }^{69}$

Manufacturing and operational considerations also had demonstrated effects on product integrity. Several studies demonstrate that appropriate handling of MABs is crucial in maintaining the integrity of the complex protein interactions including those with the solvent molecules, primary container and other surfaces the MAB may come in contact with. ${ }^{70-72}$ Not limited to MABs (or other novel agents) is the association of lesser operator technique with higher rates antimicrobial product contamination. ${ }^{73-75}$ Aseptic technique has been widely studied in relation to microbial contamination of parenteral products however not in relation to occupational exposure. Microbial contamination risk is also linked to vial-sharing outside of pharmacy controlled environments with demonstration of microbial contamination, poor expiration date documentation and failure to discard (potential use of) expired stock. ${ }^{76}$ Australian Pharmaceutical Benefits Scheme (PBS) funding is based on milligram of dose rather than vial, ${ }^{77}$ which may encourage vial-sharing.

\section{Discussion:}

Healthcare personnel at risk of occupational exposure include any staff exposed or potentially exposed to these agents or their metabolites, either through direct contact or exposure to contaminated bodily fluids such as blood, urine or faeces. Licensing of agents for subcutaneous administration (bortezomib and denosumab, ${ }^{78,79}$ likely rituximab and trastuzumab, ${ }^{80}$ and then other 
agents) is expected to lead to administration across a range of clinical and community settings outside of the hospital environment. It is therefore important that guidelines provide consistent risk assessments and unambiguous handling recommendations.

The processes involved in the preparation of many novel agents are complex, sensitive, or involve numerous and/or multifaceted manipulations (table 1) but are only considered within four published guidelines. ${ }^{33,34,81}$ Complex preparations infrequently performed or performed by inadequately trained personnel may present risks to healthcare personnel (occupational exposure) and the product (integrity and microbial contamination). Risks associated with vial-sharing on the ward ${ }^{76}$ mean that institutions with large manufacturing units and an ability to vial-share (multiple patients treated with the same drug) may seek to reap financial benefits associated with PBS reimbursement by milligram rather than vial, ${ }^{77}$ by vial-sharing within sterile manufacturing units regardless of occupational health and safety risks.

Studies evaluating the occupational exposure of novel agents (as for cytotoxic anticancer agents) are lacking and unlikely to be conducted. As such there is a reliance on animal studies, in vitro testing and pharmacologic principle. The divergent physical, molecular and pharmacokinetic profiles of novel anticancer agents compared to cytotoxic agents and other chemical substances mean that current definitions for hazardous substances are not appropriate for the classification of these agents. Australian and international hazardous substance criteria include parameters (genotoxicity, carcinogenicity) not applicable, unable to be tested or not mandated to be tested for products derived from biotechnology. ${ }^{1,2,27}$. Adding further difficulties in the classification of these agents is the evaluation of cytotoxicity and whether direct or indirect (immune-mediated) methods present equal risks to healthcare personnel. No MAB has direct cytotoxic activity nor is there a mechanism for the direct cytotoxic potential of MABs. However, they can exert cytotoxic effects via immunemodulation including antibody-dependent cellular cytotoxicity (ADCC) and complement-dependent cytotoxicity (CDC). ${ }^{30,31}$

Beyond toxicity classification, the likelihood of systemic exposure in the occupational setting impacts on the ability of these agents to exert potentially hazardous effects. The most appropriate weighting for internalisation and toxicity risk is unclear. However, it must be considered that an agent with no means of internalisation, but which is reliant on internalisation to exert toxic effects, presents no (or negligible) occupational risk. Internalisation is impacted by the divergent physiochemical properties of novel agents. FPs have similar properties to MABs, both with proteinaceous morphology and MW significantly greater than novel small molecule chemical entities (proteasome inhibitors) and 
traditional anticancer agents. Etanercept (FP) MW 130 Kilo Dalton; ${ }^{22}$ denosumab (MAB) MW 147 Kilo Dalton; ${ }^{79}$ Bortezomib (proteasome inhibitor) MW 384 Dalton; ${ }^{78}$ and Cisplatin (alkylating agent) MW 300 Dalton. ${ }^{82}$

Extrapolation of therapeutic toxicity profiles to the occupational exposure setting may be misleading considering available evidence relating to (lack of) potential systemic exposure routes for the large molecule proteinaceous agents, MABs and FPs. With no evidence of toxicity from topical contact and molecular properties limiting the likelihood of internalisation of MABs or FPs in the occupational exposure setting, these agents present with differing occupational exposure risks to cytotoxic agents and warrant different (lesser) safe handling requirements.The American National Institute for Occupational Safety and Health (NIOSH) describe disagreement between peer reviewers and stakeholders around the hazard evaluation of several MABs (bevacizumab, cetuximab and rituximab and alemtuzumab). NIOSH ultimately declined the addition of bevacizumab, cetuximab and rituximab (argued hazardous based on evidence of foetal toxicity and teratogenicity) and removed alemtuzumab (argued hazardous based on ability to cause marrow hypoplasia), due to low likelihood of substantial systemic exposure. ${ }^{83}$ Thus in the 2012 list of antineoplastic and other hazardous drugs in healthcare settings only MABs conjugated to cytotoxic agents or radio-isotopes were included. ${ }^{1}$ This conclusion however, is based on low levels of evidence and uncertainties remain which warrant a precautionary approach and consideration of interventions greater than for non-hazardous medications. Uncertainty is exemplified by the demonstration of MAB absorption (local and systemic) via oral, mucosal (nasal, vaginal and ocular), and inhalation routes, despite unfavourable molecular and physiochemical properties (high MW and size and marked hydrophillia). Particularly noteworthy is the study demonstrating ocular absorption and biological activity (local not systemic) in a rat model at very low doses $(<50 \mathrm{mcg} /$ day $),{ }^{47}$ which may reflect low doses associated with occupational exposure.

Disclosure: This work was completed as part of a Western and Central Melbourne Integrated Cancer Service (WCMICS) funded project entitled Development and promulgation of safe handling and distribution guidelines for "new" anticancer molecules by healthcare personnel including pharmacy, nursing and medical personnel. Findings from this review were used to guide the development of Australian Consensus Guidelines for the safe handling of monoclonal antibodies. 


\section{Reference List}

1. List of antineoplastic and other hazardous drugs in health care settings 2012.

National Institute for Occupational Safety and Health (NIOSH); 2012.

2. Approved Criteria for Classifying Hazardous Substances [NOHSC:1008(2004)]. Australian National Standard. 3rd Revision. National Occupational Health and Safety Commission (NOHSC); 2004.

3. EC Council Directive 67/548/EEC on the approximation of the laws raaprttc, packaging and labelling of dangerous substances, Official Journal of the European Communities, No. L196 (16 August 1967).

4. Commission Directive 2001/59/EC of 6 August 2001 adapting to technical progress for the 28th time Council Directive 67/548/EEC on the approximation of the laws, regulations and administrative provisions relating to the classification, packaging and labelling of dangerous substances, Official Journal of the European Communities, No. L225 (21 August 2001).

5. Adams J and Kauffman M. Development of the Proteasome Inhibitor Velcade ${ }^{\mathrm{TM}}$ (Bortezomib). Cancer Investigation. 2004; 22: 304-11.

6. Australian Register of Therapeutic Goods (ARTG). Therapuetic Goods Administartion (TGA). Accessed 30/09/2013. Available: https://www.ebs.tga.gov.au/.

7. U.S. Food and Drug Administration (FDA). Hematology/Oncology (Cancer) Approvals \& Safety Notifications. Accessed 30/09/2013.Available: http://www.fda.gov/Drugs/InformationOnDrugs/ApprovedDrugs/ucm279174.htm.

8. Moreau P, Richardson P, Cavo M, et al. Proteasome Inhibitors in multiple myeloma: 10 years later. Blood. 2012; 120: 947-59.

9. Bortezomib (Velcade) Material Safety Data Sheet (MSDS). Johnson and Johnson. Verson 2.0. Issue Date: 20/03/2012 (A317L).

10. SHPA. Standards of practice for the safe handling of cytotoxic drugs in pharmacy departments. Journal of Pharmacy Practice and Research. 2004; 35: 44-52.

11. Lamm DL, Thor DE, Harris SC, Reyna JA, Stogdill VD and Radwin HM. Bacillus Calmette-Guerin immunotherapy of superficial bladder cancer. J Urol. 1980; 124: 38-40.

12. Bacillus Calmette and Guerin (Oncotice) TGA Product Information. Merck Sharp \& Dohme. Revison Date 01/09/2012.

13. Ginn SL, Alexander IE, Edelstein ML, Abedi MR and Wixon J. Gene therapy clinical trials worldwide to 2012 - an update. The Journal of Gene Medicine. 2013; 15: 65-77.

14. Bamford KB, Wood S and Shaw RJ. Standards for gene therapy clinical trials based on pro-active risk assessment in a London NHS Teaching Hospital Trust. Q J Med. 2005; 98: 7586.

15. Gene Technology Act 2000. Act No. 169/2000 as amended. Compilation prepared on 24 January 2012 taking into account amendments up to Act No. 58 of 2011.

16. SHPA. Guidelines for medicines prepared in australian hospital pharmacy departments. Journal of Pharmacy Practice and Research. 2010; 40: 133-43.

17. Connor T, McLauchlan R and Vandenbroucke J. ISOPP Standards of Practice Cytotoxics. J Oncol Pharm Pract. 2007; Supplement to 13: 13-81.

18. The Scientific Advisory Committee on Genetic Modification (SACGM) compendium of guidance. Part 6: guidance on the use of genetically modified microorganisms in a clinical setting. Health and Safety Executive (HSE). First published 01/07. 
19. Liossis S-NC and Tsokos GC. Monoclonal antibodies and fusion proteins in medicine. Journal of Allergy and Clinical Immunology. 2005; 116: 721-9.

20. Guideline for the preparation or manipulation of monoclonal antibodies (MABs) and related compounds such as fusion proteins, used in the treatment of cancer. Version 2.0. Pan Birmingham Cancer Network; 2012.

21. Clinical Oncology Society of Australia, Cancer Pharmacists Group Position Statement. Safe handling of monoclonal antibodies in healthcare settings. Melbourne: Clinical Oncology Society of Australia; 2013.

22. Etanercept (Enbrel) Material Safety Data Sheet (MSDS). Amgen. Revision number 3. Issue Date: 12/02/2013.

23. Abatacept. Material Safety Data Sheet (MSDS). Bristol-Myers Squibb. Version 1.6. Issue date 04/06/2007.

24. Andrady C, Chester KA and Sharma SK. Antibody-enzyme fusion proteins for cancer therapy. Immunotherapy. 2011; 3: 193-211.

25. Mascelli MA, Zhou H, Sweet R, et al. Molecular, Biologic, and Pharmacokinetic Properties of Monoclonal Antibodies: Impact of these parameters on early clinical development. The Journal of Clinical Pharmacology. 2007; 47: 553-65.

26. Mellor JD, Brown MP, Irving HR, Zalcberg JR and Dobrovic A. A critical review of the role of Fc gamma receptor polymorphisms in the response to monoclonal antibodies in cancer. Journal of Hematology \& Oncology. 2013; 6: 1-10.

27. Guidance for Industry S6 Preclinical Safety Evaluation of Biotechnology-Derived Pharmaceuticals (ICH S6). International Conference on Harmonisation of Technical Requirements for Registration of Pharmaceuticals for Human Use (ICH); 1997.

28. Maibach $\mathrm{H}$ and Conant $\mathrm{M}$. Contact urticaria to a corticosteroid cream: polysorbate 60. Contact Dermatitis. 2006; 3: 350-1.

29. Kerwin BA. Polysorbates 20 and 80 used in the formulation of protein biotherapeutics: structure and degradation pathways. Journal of pharmaceutical sciences. 2008; 97: 2924-35.

30. Overdijk MB, Verploegen S, van den Brakel JH, et al. Epidermal growth factor receptor (EGFR) antibody-induced antibody-dependent cellular cytotoxicity plays a prominent role in inhibiting tumorigenesis, even of tumor cells insensitive to EGFR signaling inhibition. Journal of immunology (Baltimore, Md : 1950). 2011; 187: 3383-90.

31. Ueda N, Tsukamoto H, Mitoma H, et al. The cytotoxic effects of certolizumab pegol and golimumab mediated by transmembrane tumor necrosis factor $\alpha$. Inflamm Bowel Dis. 2013; 19: 1224-31.

32. Halsen $\mathrm{G}$ and Kramer I. Assessing the risk to health care staff from long-term exposure to anticancer drugs--the case of monoclonal antibodies. Journal of oncology pharmacy practice : official publication of the International Society of Oncology Pharmacy Practitioners. 2011; 17: 68-80.

33. Langford S, Fradgley S, Evans $M$ and Blanks $C$. Assessing the risk of handling monoclonal antibodies. Hospital Pharmacist. 2008; 15: 60-4.

34. Monoclonal antibodies risk management for Northern Sydney Local Health District (NSLHD). Document number PR2013_001. Department of Oncology, Division of Medicine, Northern Sydney Local Health District hospitals; 2013.

35. de Goede A, Zandvliet $M$ and Kosterink J. Occupational risk of anticancer monoclonal antibodies. EJHP Practice. 2011; 17: 62-4. 
36. Moss GP, Dearden JC, Patel H and Cronin MTD. Quantitative structure-permeability relationships (QSPRs) for percutaneous absorption. Toxicology in Vitro. 2002; 16: 299-317. 37. Bos JD and Meinardi MM. The 500 Dalton rule for the skin penetration of chemical compounds and drugs. Experimental dermatology. 2000; 9: 165-9.

38. Dostalek M, Gardner I, Gurbaxani BM, Rose RH and Chetty M. Pharmacokinetics, pharmacodynamics and physiologically-based pharmacokinetic modelling of monoclonal antibodies. Clin Pharmacokinet. 2013; 52: 83-124.

39. Kaestli L, Fonzo-Christe C, Bonfillon C, Desmeules J and Bonnabry P. Development of a standardised method to recommend protective measures to handle hazardous drugs in hospitals. Eur J Hosp Pharm. 2013; 20: 100-5.

40. Blink R. Concepts of Occupational Exposure to Monoclonal Antibodies [unpublished work]. Appendix in BioPharma Environmental Health and Safety (EHS) Group public correspondence to NIOSH. Accessed 22/08/2013. Available:

http://www.cdc.gov/niosh/docket/archive/pdfs/NIOSH-105/0105-092007-treanor_sub.pdf. 2007.

41. Maillet A, Congy-Jolivet N, Le Guellec S, et al. Aerodynamical, immunological and pharmacological properties of the anticancer antibody cetuximab following nebulization. Pharmaceutical research. 2008; 25: 1318-26.

42. Lightwood D, O'Dowd V, Carrington B, et al. The Discovery, Engineering and Characterisation of a Highly Potent Anti-Human IL-13 Fab Fragment Designed for Administration by Inhalation. Journal of Molecular Biology. 2013; 425: 577-93.

43. Kim S. Low Inhalation Bioavailablity of mABs. Unpublished Work [appendix in correspondence from BioPharma EHS Forum to NIOSH] Accessed 01/04/2013 Available: http://wwwcdcgov/niosh/docket/archive/pdfs/NIOSH-105/0105-092007-treanor_subpdf. 2007.

44. Saltzman WM, Sherwood JK, Adams DR, Castle P and Haller P. Long-term vaginal antibody delivery: delivery systems and biodistribution. Biotechnology and bioengineering. 2000; 67: 253-64.

45. Samson G, Garcia de la Calera A, Dupuis-Girod S, et al. Ex vivo study of bevacizumab transport through porcine nasal mucosa. European journal of pharmaceutics and biopharmaceutics : official journal of Arbeitsgemeinschaft fur Pharmazeutische Verfahrenstechnik eV. 2012; 80: 465-9.

46. Falero-Diaz G, Challacombe S, Rahman D, et al. Transmission of IgA and IgG monoclonal antibodies to mucosal fluids following intranasal or parenteral delivery. International archives of allergy and immunology. 2000; 122: 143-50.

47. Pleyer U, Milani JK, Dukes A, et al. Effect of topically applied anti-CD4 monoclonal antibodies on orthotopic corneal allografts in a rat model. Investigative ophthalmology \& visual science. 1995; 36: 52-61.

48. Alemtuzumab (Campath) Material Safety Data Sheet (MSDS). Berlex Biosciences. Revision Date: 04/06/2002.

49. Bevacizumab (Avastin) Material Safety Data Sheet (MSDS). Roche. Revision Date: 01/03/2013.

50. Ofatumumab (Arzerra) Material Safety Data Sheet (MSDS). GlaxoSmithKline. Version 4. Revision Date: 12/11/2009 (131072).

51. Ochi $\mathrm{H}$, Abraham $\mathrm{M}$, Ishikawa $\mathrm{H}$, et al. Oral CD3-specific antibody suppresses autoimmune encephalomyelitis by inducing CD4+ CD25- LAP+ T cells. Nature medicine. 2006; 12: 627-35. 
52. Petschow BW and Talbott RD. Reduction in virus-neutralizing activity of a bovine colostrum immunoglobulin concentrate by gastric acid and digestive enzymes. Journal of pediatric gastroenterology and nutrition. 1994; 19: 228-35.

53. Tacket $\mathrm{CO}$, Losonsky $\mathrm{G}$, Link $\mathrm{H}$, et al. Protection by milk immunoglobulin concentrate against oral challenge with enterotoxigenic Escherichia coli. The New England journal of medicine. 1988; 318: 1240-3.

54. Vermeer AW and Norde W. The thermal stability of immunoglobulin: unfolding and aggregation of a multi-domain protein. Biophysical journal. 2000; 78: 394-404.

55. Siderov J KS, McLauchlan R. Surface Contamination of Cytotoxic Chemotherapy Preparation Areas in Australian Hospital Pharmacy Departments. Journal of Pharmacy Practice and Research. 2009; 39: 117-21.

56. Kiffmeyer T.K, Kube C, S O, et al. Vapour pressures, evaporation behaviour and airborne concentrations of hazardous drugs: implications for occupational safety. The Pharmaceutical Journal. 2002; 268: 33.

57. Fransman W, Vermeulen R and Kromhout H. Occupational dermal exposure to cyclophosphamide in Dutch hospitals: a pilot study. The Annals of occupational hygiene. 2004; 48: 237-44.

58. Australian and New Zealand Standard. AS/NZS 1716:2012. Respiratory protective devices. Seventh edition. Standards Australia Limited / Standards New Zealand.

59. Australian and New Zealand Standard. AS/NZS 1715:2009. Selection, use and maintainance of respiratory protective equipment. Standards Australia Limited / Standards New Zealand.

60. The cytotoxics handbook - 4th edition. In: Allwood. M SA, Wright. P, (ed.). Abingdon, UK: Radcliffe Medical Press, 2002.

61. Harrison. B KM. Penetration and splash protection of six disposable gown materials against fifteen antineoplastic drugs. J Oncol Pharm Pract. 1999; 5: 61-6.

62. Jorgenson J, Spivey S, Canann D, Ritter H and Smith B. Contamination comparison of transfer devices intended for handling hazardous drugs. Hospital Pharmacy. 2008; 43: 7237.

63. McMichael D, Jefferson D, Carey E, et al. Utility of the PhaSeal closed system drug transfer device. American Journal of Pharmacy Benefits. 2011; 3: 9-16.

64. Siderov J KS, McLauchlan R. Reducing workplace cytotoxic surface contamination using a closed-system drug transfer device. J Oncol Pharm Pract. 2010; 16: 19-25.

65. Harrison BR PB, Bing MR. Comparison of surface contamination with cyclophosphamide and fluorouracil using a closed-system drug transfer device versus standard preparation techniques. Am J Health-Syst Pharm. 2006; 63: 1736-44.

66. Sessink P RM, Ryden N. Evaluation of the PhaSeal hazardous drug containment system. Hospital Pharmacy. 1999; 34: 1311-7.

67. Spivey SM CT. Determining sources of workplace contamination with antineoplastic drugs and comparing conventional IV preparation with a closed system. Hospital Pharmacy. 2003; 38: 135-9.

68. Biron $A D$, Lavoie-Tremblay $M$ and Loiselle $C G$. Characteristics of work interruptions during medication administration. J Nurs Scholarsh. 2009; 41: 330-6.

69. Raban $\mathrm{MZ}$ and Westbrook Jl. Are interventions to reduce interruptions and errors during medication administration effective?: a systematic review. BMJ quality \& safety. 2013. 
70. Kiese S, Papppenberger A, Friess W and Mahler H. Shaken, not stirred: mechanical stress testing of an IgG1 antibody. Journal of pharmaceutical sciences. 2008; 97: 4347-66. 71. Sreedhara A, Glover ZK, Piros N, Xiao N, Patel A and Kabakoff B. Stability of IgG1 monoclonal antibodies in intravenous infusion bags under clinical in-use conditions. Journal of pharmaceutical sciences. 2012; 101: 21-30.

72. Wang W, Singh S, Zeng D, King K and Nema S. Antibody structure, instability and formulation. Journal of pharmaceutical sciences. 2007; 96: 1-26.

73. Austin $\mathrm{P}$ and Elia M. Improved aseptic technique can reduce variable contamination rates of ward-prepared parenteral doses. Journal of Hospital Infection. 2013; 83: 160-3.

74. Thomas M, Sanborn $\mathrm{M}$ and Couldry R. I.V. admixture contamination rates:

Traditional practice site versus a class 1000 cleanroom. Am J Health Syst Pharm. 2005; 62: 2386-92.

75. Trissel L, Gentempo J, Anderson R and LaJeunesse J. Using a medium-fill simulation to evaluate the microbial contamination rate for USP medium-risk-level compounding. Am J Health Syst Pharm. 2005; 62: 285-8.

76. Mattner $F$ and Gastmeier P. Bacterial contamination of multiple-dose vials: a prevalence study. American Journal of Infection Control. 2004; 32: 12-6.

77. Pricing of PBS Medicine. Average rates payable for extemporaneous items. Medicare, Australian Government Department of Human Services. Accessed 08/05/13. Available: https://www.medicareaustralia.gov.au/provider/pbs/pharmacists/pricing.jsp\#N102DE. 78. Bortezomib (Velcade) Product Information. Jannsen. Revision date: 20/11/2012. 79. Denosumab (Xgeva) Product Information. Amgen. Revision Date: 05/03/2013. 80. Shpilberg $\mathrm{O}$ and Jackisch C. Subcutaneous administration of rituximab (MabThera) and trastuzumab (Herceptin) using hyaluronidase. British journal of cancer. 2013; 109: 155661.

81. Lilly E. Gemcitabine (Gemzar). Approved Product Information. ARTG approval date: 02/08/1995. Revision date: 16/06/2013: (2013).

82. Cisplatin (cas 15663-27-1) Material Safety Data Sheet (MSDS). GuideChem. .

83. List of antineoplastic and other hazardous drugs in healthcare settings 2012: proposed additions and deletions to the NIOSH hazardous drug list-charge to reviewers. National Institute for Occupational Safety and Health (NIOSH). Accessed 31/05/2013. Available: http://www.cdc.gov/niosh/docket/archive/pdfs/NIOSH-190/0190010112-chargeToReviewers.pdf.

84. Aflibercept (Eylea) Material Safety Data Sheet (MSDS). Bayer Australia Ltd. Version 1.0. Revision Date: $22 / 09 / 2011$.

85. Aflibercept (Eylea) Product Information. Bayer Australia Ltd. Revision date: 05/04/2013.

86. Alemtuzumab (Campath) FDA Product Information. Genzyme Corporation. Revision date: 19/09/2007.

87. Alemtuzumab (MabCampath) TGA Product Information. Genzyme Australasia Pty Ltd. Revision date: 20/06/2012.

88. Bacillus Calmette-Guerin (OncoTICE) Material Safety Data Sheet (MSDS). MSD, Merck \& Co., Inc. Revision Date: 04/04/2011

89. Rainwater DL and Kolattukudy PE. Fatty acid biosynthesis in Mycobacterium tuberculosis var. bovis Bacillus Calmette-Guerin. Purification and characterization of a novel 
fatty acid synthase, mycocerosic acid synthase, which elongates n-fatty acyl-CoA with methylmalonyl-CoA. The Journal of biological chemistry. 1985; 260: 616-23.

90. Bevacizumab (Avastin). FDA Product Information. Roche. Revision date: 03/2013.

91. Bevacizumab (Avastin). TGA Product Information. Roche. Revision date: 09/05/2013.

92. Brentuximab-Vedotin (Adcetris) FDA Product Information. SeattleGenetics. Revision date: $01 / 2012$.

93. SeattleGenetics. Brentuximab-Vedotin (914088-09-8) Material Safety Data Sheet (MSDS). Clearsynth. 2012.

94. Cetuximab (Erbitux) Material Safety Data Sheet (MSDS). ImClone Systems Incorporated. Revision Date: 02/2005.

95. Cetuximab (Erbitux) TGA Product Information. Merk Serono. Revision Date: $14 / 05 / 2013$.

96. Denosumab (Xgeva) Material Safety Data Sheet (MSDS). Amgen. Version 3. Revision Date: 01/02/2013.

97. Denosumab (Prolia) Material Safety Data Sheet (MSDS). Amgen. Version 6. Revision Date 01/02/2013.

98. Denosumab (Prolia) Product Information. Amgen. Revision Date: 24/04//2013.

99. Ipilimumab (Yervoy). FDA Product Information. Bristol-MyersSquibb. Revision date: 05/2013.

100. Ipilimumab (Yervoy). TGA Product Information.Bristol-Myers Squibb. Revision date: 16/05/2013.

101. Ipilimumab (Yervoy) Material Safety Data Sheet (MSDS). Bristol-Myers Squibb. Version 7.1. Revision Date 15/04/2011.

102. Ofatumumab (Arzerra) FDA Product Information. GlaxoSmithKline. Revision date: 09/2011.

103. Panitumumab (Vectibix) FDA Product Information. Amgen. Revision date: 03/2013.

104. Panitumumab (Vectibix) Material Safety Data Sheet (MSDS). Amgen. Version 2.

Revision Date: 08/05/2008.

105. Panitumumab (Vectibix) TGA Product Information. Amgen. Revision date:

21/05/2013.

106. Rituximab (Mabthera). TGA Product Information. Roche. Revision date: 13/05/2013.

107. Rituximab (Mabthera) Material Safety Data Sheet (MSDS). Roche. Revision Date:

22/10/2009.

108. Trastuzumab (Herceptin) FDA Product Information. Roche. Revision date: 10/2012.

109. Trastuzumab (Herceptin) TGA Product Information. Roche. Revision date:

$13 / 08 / 2012$.

110. Trastuzumab (Herceptin) Material Safety Data Sheet (MSDS). Roche. Revision Date: 01/03/2013.

111. Trastuzumab-Emtansine (Kadcyla) FDA Product Information. Genentech. Revision date: $05 / 2013$.

112. Trastuzumab-Emtansine (Kadcyla) Material Safety Data Sheet (MSDS). Roche.

Revision Date: $26 / 04 / 13$

113. Dangerous Goods Act 1985. Act No. 10189/1985. Version No. 081. (1985). Retrieved from www.austlii.edu.au: (1985).

114. Dangerous Goods (Storage and Handling) Regulations (Victoria). S.R. No. 132/2012: (2012). 
115. Occupational Health and Safety Act 1985. Act No. 10190/1985. Version No. 061: (1985).

116. Victorian Government. Occupational Health and Safety Regulations. S.R. No. 54/2007. Version No. 001: (2007).

117. Workplace exposure standards for airborne contaminants. April 2013. Safe Work Australia.

118. Work Safe Victoria. Handling cytotoxic drugs in the workplace.Work Safe Victoria, State Government of Victoria; 2003.

119. The Handling of Hazardous Drugs and Related Wastes in South Australian Health Services. Policy - Public Health and Clinical Systems. Approved 02/04/2012. Accessed 31/05/2013. Available:

http://www.sahealth.sa.gov.au/wps/wcm/connect/f99069004b3f738aa4ddade79043fafo/H andlingOfHazardousDrugsRelatedWastesinSADirective-PHCS-PSS-

1205.pdf?MOD=AJPERES\&CACHEID=f99069004b3f738aa4ddade79043faf0.

120. ASCO. American Society of Clinical Oncology/Oncology Nursing Society

Chemotherapy Administration Safety Standards. 2012.

121. WHO. Good manufacturing practices for pharmaceutical products containing hazardous substances. 2010.

122. NHS. Guidance on the safe handling of monoclonal antibody (MAB) products. 4th Edition: (2008). 
Table 1 - Drug Evaluations

\begin{tabular}{|c|c|c|c|c|c|c|c|c|c|c|c|c|}
\hline Drug & Class & $\begin{array}{l}\text { Direct } \\
\text { Cytotoxic } \\
\text { Activity } \\
\end{array}$ & $\begin{array}{l}\text { Low Dose } \\
\text { Organ } \\
\text { Toxicity } \\
\end{array}$ & Immunogenic & Teratogenic & Mutagenic & Carcinogenic & $\begin{array}{c}\text { MW } \\
\text { (Dalton) }\end{array}$ & Stability & Sterility & $\begin{array}{l}\text { Prep. } \\
\text { Steps }\end{array}$ & $\begin{array}{l}\text { Admin. } \\
\text { Route }\end{array}$ \\
\hline Aflibercept ${ }^{84,85}$ & $\begin{array}{l}\text { Fusion } \\
\text { Protein }\end{array}$ & No* & No & $\begin{array}{l}\text { ADA: } 3.3 \% \\
\text { HSR: } 0.3 \% \\
\text { IRR: nil }\end{array}$ & $\begin{array}{l}\text { Yes; animal } \\
\text { studies }\end{array}$ & $\begin{array}{l}\text { No data; not } \\
\text { expected } \\
\text { based on } \\
\text { pharmacology }\end{array}$ & No data & 115,000 & $\begin{array}{l}\text { Until expiry } \\
\text { at } 2-8^{\circ} \mathrm{C}\end{array}$ & $\begin{array}{l}24 \text { hours } \\
\text { at } 25^{\circ} \mathrm{C}\end{array}$ & 2 & IV \\
\hline $\begin{array}{l}\text { Alemtuzumab }{ }^{48,} \\
86,87\end{array}$ & $\begin{array}{l}\text { Fully } \\
\text { humanised } \\
\text { MAB }\end{array}$ & No* & No & $\begin{array}{l}\text { ADA: } 8.3 \% \\
\text { HSR: }<1 \% \\
\text { IRR: } 10-35 \%\end{array}$ & $\begin{array}{l}\text { No data; unlikely } \\
\text { to cross placenta } \\
\text { due to molecular } \\
\text { size; theoretical } \\
\text { risk if it did }\end{array}$ & No data & No data & 150,000 & $\begin{array}{l}8 \text { hours at } \\
2-8^{\circ} \mathrm{C}\end{array}$ & $\begin{array}{l}8 \text { hours at } \\
2-8^{\circ} \mathrm{C}\end{array}$ & 2 & IV \\
\hline $\begin{array}{l}\text { Bacillus } \\
\text { Calmette-Guerin } \\
(\mathrm{BCG})^{11,88,89}\end{array}$ & $\begin{array}{l}\text { Live Vaccine } \\
\text { / Immuno- } \\
\text { stimulant }\end{array}$ & No & No & No data & $\begin{array}{l}\text { No data; } \\
\text { expected based } \\
\text { on pharmacology }\end{array}$ & No data & No data & 238,000 & $\begin{array}{l}2 \text { hours at } \\
2-8^{\circ} \mathrm{C}\end{array}$ & $\begin{array}{l}2 \text { hours at } \\
2-8^{\circ} \mathrm{C}\end{array}$ & 7 & $\begin{array}{l}\text { Bladder } \\
\text { instil }^{\mathrm{n}}\end{array}$ \\
\hline $\begin{array}{l}\text { Bevacizumab }{ }^{49,} \\
90,91\end{array}$ & $\begin{array}{l}\text { Fully } \\
\text { humanised } \\
\text { MAB }\end{array}$ & No* & No & $\begin{array}{l}\text { ADA: } 0.63 \% \\
\text { HSR/IRR: }<5 \%\end{array}$ & $\begin{array}{l}\text { Yes; animal } \\
\text { studies; }\end{array}$ & No data & No data & 149,000 & $\begin{array}{l}48 \text { hours at } \\
2-30^{\circ} \mathrm{C}\end{array}$ & $\begin{array}{l}24 \text { hours } \\
\text { at } 2-8^{\circ} \mathrm{C}\end{array}$ & 2 & IV \\
\hline Bortezomib $^{9,78}$ & $\begin{array}{l}\text { Proteasome } \\
\text { Inhibitor }\end{array}$ & Yes & No & No data & $\begin{array}{l}\text { Yes; animal } \\
\text { studies }\end{array}$ & $\begin{array}{l}\text { No; negative } \\
\text { in vitro and in } \\
\text { vivo tests }\end{array}$ & $\begin{array}{l}\text { Activity } \\
\text { demonstrated } \\
\text { in in vitro } \\
\text { testing } \\
\end{array}$ & 384 & $\begin{array}{l}8 \text { hours at } \\
2-8^{\circ} \mathrm{C}\end{array}$ & $\begin{array}{l}8 \text { hours at } \\
2-8^{\circ} \mathrm{C}\end{array}$ & 2 & IV or SC \\
\hline $\begin{array}{l}\text { Brentuximab } \\
\text { Vedotin }^{92,93}\end{array}$ & $\begin{array}{l}\text { Antibody } \\
\text { Drug } \\
\text { Conjugate } \\
\end{array}$ & $\begin{array}{l}\text { Yes } * \\
\text { (vedotin) }\end{array}$ & No & $\begin{array}{l}\text { ADA: } 7-30 \% \\
\text { HSR/IRR: } 12 \%\end{array}$ & $\begin{array}{l}\text { Yes; animal } \\
\text { studies }\end{array}$ & $\begin{array}{l}\text { Yes; animal } \\
\text { studies }\end{array}$ & No data & 153,000 & $\begin{array}{l}24 \text { hours at } \\
2-8 \mathrm{deg}\end{array}$ & $\begin{array}{l}24 \text { hours } \\
\text { at 2-8deg }\end{array}$ & $6-8$ & IV \\
\hline Cetuximab $^{32,94,95}$ & $\begin{array}{l}\text { Human- } \\
\text { murine } \\
\text { MAB }\end{array}$ & No* & No & $\begin{array}{l}\text { ADA: } 3.4 \% \\
\text { HSR/IRR: } 14 \%\end{array}$ & $\begin{array}{l}\text { Negative in } \\
\text { animal studies; } \\
\text { expected based } \\
\text { on pharmacology }\end{array}$ & $\begin{array}{l}\text { No; negative } \\
\text { in vitro and in } \\
\text { vivo tests }\end{array}$ & No data & 152,000 & $\begin{array}{l}48 \text { hours at } \\
25^{\circ} \mathrm{C}\end{array}$ & $\begin{array}{l}24 \text { hours } \\
\text { at } 25^{\circ} \mathrm{C}\end{array}$ & $2-3$ & IV \\
\hline $\begin{array}{l}\text { Denosumab }{ }^{79,96-} \\
98\end{array}$ & $\begin{array}{l}\text { Fully } \\
\text { humanised } \\
\text { MAB }\end{array}$ & No* & No & $\begin{array}{l}\text { ADA: }<1 \% \\
\text { HSR: } 0.9 \\
\text { IRR: nil }\end{array}$ & Conflicting data & $\begin{array}{l}\text { No data; not } \\
\text { expected } \\
\text { based on } \\
\text { pharmacology }\end{array}$ & $\begin{array}{l}\text { No data; not } \\
\text { expected } \\
\text { based on } \\
\text { pharmacology }\end{array}$ & 147,000 & $\begin{array}{l}\text { Until expiry } \\
\text { at } 2-8^{\circ} \mathrm{C}\end{array}$ & $\begin{array}{l}30 \text { days at } \\
25^{\circ} \mathrm{C}\end{array}$ & $\begin{array}{l}0 \text { (Prolia) } \\
1 \text { (Xgeva) }\end{array}$ & SC \\
\hline Ipilimumab ${ }^{99-101}$ & $\begin{array}{l}\text { Fully } \\
\text { humanised } \\
\text { MAB }\end{array}$ & No* & No & $\begin{array}{l}\text { ADA: } 1.1 \% \\
\text { HSR: }<1 \% \\
\text { IRR: }<1 \%\end{array}$ & $\begin{array}{l}\text { Yes; animal } \\
\text { studies }\end{array}$ & $\begin{array}{l}\text { Negative in } \\
\text { vitro and in } \\
\text { vivo tests }\end{array}$ & $\begin{array}{l}\text { No; animal } \\
\text { studies }\end{array}$ & 148,000 & $\begin{array}{l}24 \text { hours at } \\
25 \text { or } 2-8^{\circ} \mathrm{C}\end{array}$ & $\begin{array}{l}24 \text { hours } \\
\text { at } 2-8^{\circ} \mathrm{C}\end{array}$ & 2 & IV \\
\hline
\end{tabular}




\begin{tabular}{|c|c|c|c|c|c|c|c|c|c|c|c|c|}
\hline Drug & Class & $\begin{array}{l}\text { Direct } \\
\text { Cytotoxic } \\
\text { Activity } \\
\end{array}$ & $\begin{array}{l}\text { Low Dose } \\
\text { Organ } \\
\text { Toxicity } \\
\end{array}$ & Immunogenic & Teratogenic & Mutagenic & Carcinogenic & $\begin{array}{c}\text { MW } \\
\text { (Dalton) }\end{array}$ & Stability & Sterility & $\begin{array}{l}\text { Prep. } \\
\text { Steps }\end{array}$ & $\begin{array}{c}\text { Admin. } \\
\text { Route }\end{array}$ \\
\hline $\begin{array}{l}\text { Ofatumumab } \\
{ }_{102}\end{array}$ & $\begin{array}{l}\text { Fully } \\
\text { humanised } \\
\text { MAB }\end{array}$ & No* & & $\begin{array}{l}\text { ADA: nil } \\
\text { HSR: } 4 \% \\
\text { IRR: } 44 \%\end{array}$ & $\begin{array}{l}\text { No; animal } \\
\text { studies }\end{array}$ & $\begin{array}{l}\text { No; animal } \\
\text { studies }\end{array}$ & $\begin{array}{l}\text { No; animal } \\
\text { studies }\end{array}$ & 149,000 & $\begin{array}{l}24 \text { hours at } \\
2-8^{\circ} \mathrm{C}\end{array}$ & $\begin{array}{l}24 \text { hours } \\
\text { at } 2-8^{\circ} \mathrm{C}\end{array}$ & $\begin{array}{c}300 \mathrm{mg}=6 \\
2 \mathrm{~g}=23\end{array}$ & IV \\
\hline $\begin{array}{l}\text { Panitumumab }{ }^{103-} \\
105\end{array}$ & $\begin{array}{l}\text { Fully } \\
\text { humanised } \\
\text { MAB }\end{array}$ & No* & No & $\begin{array}{l}\text { ADA: } 0.4- \\
3.8 \% \\
\text { HSR: }<1 \% \\
\text { IRR: } 3 \%\end{array}$ & $\begin{array}{l}\text { No; animal } \\
\text { studies }\end{array}$ & No data & No data & 147,000 & $\begin{array}{l}24 \text { hours at } \\
2-8^{\circ} \mathrm{C}\end{array}$ & $\begin{array}{l}24 \text { hours } \\
\text { at } 2-8^{\circ} \mathrm{C}\end{array}$ & 2 & IV \\
\hline $\begin{array}{l}\text { Rituximab }^{80,106,} \\
107\end{array}$ & $\begin{array}{l}\text { Human- } \\
\text { murine } \\
\text { MAB }\end{array}$ & No* & No & $\begin{array}{l}\text { ADA: } 12.7 \% \\
\text { HSR: } 1-10 \% \\
\text { IRR: } 15 \%\end{array}$ & $\begin{array}{l}\text { No; post- } \\
\text { marketing human } \\
\text { case reports \& } \\
\text { animal studies }\end{array}$ & No data & No data & 144,000 & $\begin{array}{l}2-8^{\circ} \mathrm{C} \\
\text { No time } \\
\text { specified } \\
\text { for dilution } \\
\text { solution }\end{array}$ & $\begin{array}{l}2-8^{\circ} \mathrm{C} \\
\text { No time } \\
\text { specified } \\
\text { for } \\
\text { dilution } \\
\text { solution } \\
\end{array}$ & 2 & IV, SC \\
\hline $\begin{array}{l}\text { Trastuzumab } \\
\text { 108-110 }\end{array}$ & $\begin{array}{l}\text { Human- } \\
\text { murine } \\
\text { MAB }\end{array}$ & No* & No & $\begin{array}{l}\text { ADA: } 0.1 \% \\
\text { HSR: } 0.6 \% \\
\text { IRR: } 21-35 \%\end{array}$ & $\begin{array}{l}\text { Yes; post- } \\
\text { marketing human } \\
\text { case reports. } \\
\text { No; animal } \\
\text { studies }\end{array}$ & $\begin{array}{l}\text { Negative in } \\
\text { vitro and in } \\
\text { vivo tests }\end{array}$ & No data & 148,000 & $\begin{array}{l}24 \text { hours at } \\
30^{\circ} \mathrm{C}\end{array}$ & $\begin{array}{l}24 \text { hours } \\
\text { at } 2-8 \mathrm{deg}\end{array}$ & 5 & IV, SC \\
\hline $\begin{array}{l}\text { Trastuzumab- } \\
\text { Emtansine }^{111,112}\end{array}$ & $\begin{array}{l}\text { Antibody } \\
\text { Drug } \\
\text { Conjugate }\end{array}$ & $\begin{array}{l}\text { Yes * } \\
\text { (emtansine) }\end{array}$ & No & $\begin{array}{l}\text { ADA: } 5.3 \% \\
\text { HSR: } 2.2 \% \\
\text { IRR: } 1.4 \%\end{array}$ & $\begin{array}{l}\text { No data; } \\
\text { expected based } \\
\text { on pharmacology } \\
\text { of emtansine and } \\
\text { trastuzumab } \\
\text { post-marketing }\end{array}$ & $\begin{array}{l}\text { Aneugenic/ } \\
\text { Clastogenic in } \\
\text { in vivo testing, } \\
\text { Negative in in } \\
\text { vitro testing }\end{array}$ & No data & 148,000 & $\begin{array}{l}4 \text { hours at } \\
2-8^{\circ} \mathrm{C}\end{array}$ & $\begin{array}{l}4 \text { hours at } \\
2-8^{\circ} \mathrm{C}\end{array}$ & 5 & IV \\
\hline
\end{tabular}

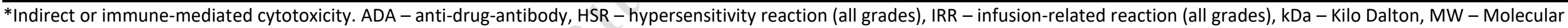
Weight, Prep - preparation, Admin - administration, IV - intravenous, SC - subcutaneous, instil ${ }^{\mathrm{n}}$ - instillation 
Table 2 - Guidelines for the handling of hazardous substances

\begin{tabular}{|c|c|c|c|}
\hline Title & Author / Date & Scope & Inclusion of novel anticancer agents \\
\hline Dangerous Goods Act $1985^{113}$ & \multirow{5}{*}{$\begin{array}{l}\text { Australian } \\
\text { Commonwealth } \\
\text { Government }\end{array}$} & \multirow{4}{*}{$\begin{array}{l}\text { Dangerous goods and } \\
\text { hazardous substances }\end{array}$} & \multirow{4}{*}{ Do not fulfil criteria / not included } \\
\hline Dangerous Goods (Storage and Handling) Regulations $2012^{114}$ & & & \\
\hline Occupational Health and Safety Act $1985^{115}$ & & & \\
\hline Occupational Health and Safety Regulations $2007{ }^{116}$ & & & \\
\hline Gene Technology Act $2000^{15}$ & & Gene therapies & $\nabla$ Gene therapy \\
\hline Workplace exposure standards for airborne contaminants ${ }^{117}$ & $\begin{array}{l}\text { Safe Work } \\
\text { Australia } 2013 \\
\end{array}$ & Airborne contaminants & $凶$ Do not fulfil criteria/ not included \\
\hline Handling cytotoxic drugs in the workplace ${ }^{118}$ & $\begin{array}{l}\text { Worksafe Victoria, } \\
2003\end{array}$ & Cytotoxic drugs & $凶$ Do not fulfil criteria/ not included \\
\hline Approved criteria for classifying hazardous substances ${ }^{2}$ & NOHSC, 2004 & Hazardous substances & 凶 Do not fulfil criteria \\
\hline $\begin{array}{l}\text { The Handling of Hazardous Drugs and Related Wastes in South } \\
\text { Australian Health Services }{ }^{119}\end{array}$ & $\begin{array}{l}\text { South Australia } \\
\text { Health, } 2012 \\
\end{array}$ & Hazardous substances & $\begin{array}{l}\square \text { Identified as a subset of hazardous drugs - referred to cytotoxic } \\
\text { drug policy (below) }\end{array}$ \\
\hline $\begin{array}{l}\text { Safe Handling of Cytotoxic Drugs and Related Waste: Guidelines for } \\
\text { South Australian Health Services } \\
119\end{array}$ & $\begin{array}{l}\text { South Australia } \\
\text { Health, } 2012 \\
\end{array}$ & Cytotoxic drugs & $\checkmark$ Discussed but no formal recommendations given. \\
\hline $\begin{array}{l}\text { NIOSH list of antineoplastic and other hazardous drugs in Healthcare } \\
\text { Settings }^{1}\end{array}$ & NIOSH, 2012 & $\begin{array}{l}\text { Antineoplastic and } \\
\text { Hazardous substances }\end{array}$ & $凶$ Do not fulfil criteria unless conjugated to cytotoxic / radioisotope \\
\hline Chemotherapy Administration Safety Standards ${ }^{120}$ & ASCO / ONS, 2012 & Chemotherapy agents & $\checkmark$ Included as chemotherapy (no separate recommendations) \\
\hline $\begin{array}{l}\text { Good manufacturing practices for pharmaceutical products containing } \\
\text { hazardous substances }{ }^{121}\end{array}$ & WHO, 2010 & Hazardous substances & $凶$ do not fulfil criteria \\
\hline ISOPP Standards of Practice ${ }^{17}$ & ISOPP, 2007 & Hazardous substances & $\begin{array}{l}\otimes \text { do not fulfil criteria *notation that 'some' MABs satisfy criteria } \\
\text { but no specification or further comment }\end{array}$ \\
\hline $\begin{array}{l}\text { Guidelines for Medicines Prepared in Australian Hospital Pharmacy } \\
\text { Departments }{ }^{16}\end{array}$ & SHPA, 2010 & Medicines & $\begin{array}{l}\square \text { Recommends dedicated clean areas and consideration of CSDTDs } \\
\text { for hazardous or sensitising products. Dedicated negative pressure } \\
\text { (containment) clean areas are recommended for MABs, gene } \\
\text { therapies and other biologically active substances }\end{array}$ \\
\hline $\begin{array}{l}\text { Standards of Practice for the safe handling of cytotoxic drugs in } \\
\text { pharmacy departments }{ }^{10}\end{array}$ & SHPA, 2004 & $\begin{array}{l}\text { Cytotoxic and other } \\
\text { hazardous drugs }\end{array}$ & 凶 Do not fulfil criteria \\
\hline $\begin{array}{l}\text { Development of a standardised method to recommend protective } \\
\text { measures to handle hazardous drugs in hospitals }\end{array}$ & Kaestli, 2013 & $\begin{array}{l}\text { Hazardous substances } \\
\text { including monoclonal } \\
\text { antibodies }\end{array}$ & $\begin{array}{l}\square \text { Pharmacy compounding not deemed necessary for any MABs (as } \\
\text { not considered hazardous), only recommended wearing gloves (and } \\
\text { masks for powder formulations) during handling. }\end{array}$ \\
\hline
\end{tabular}

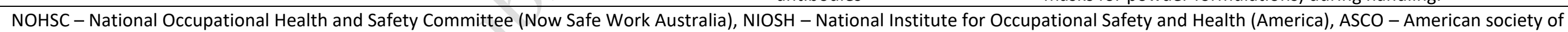

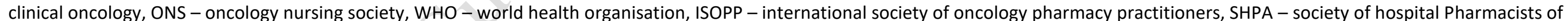
Australia, MABs - monoclonal antibodies. 
Table 3 - Guidelines for the handling of Monoclonal Antibodies (MABs)

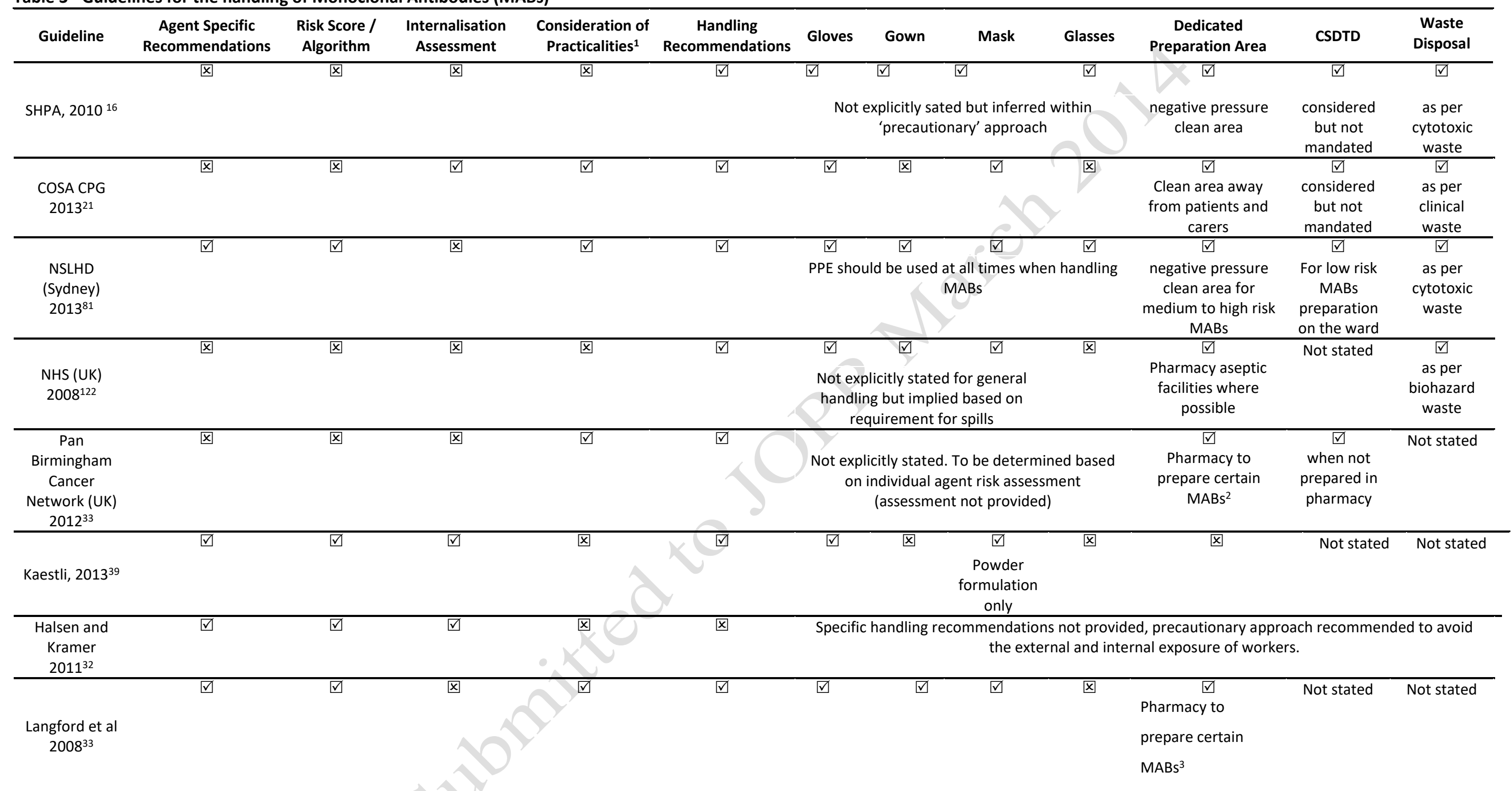

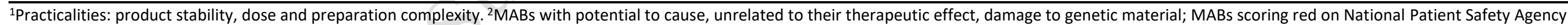

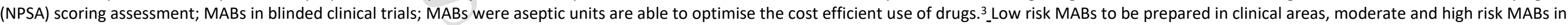

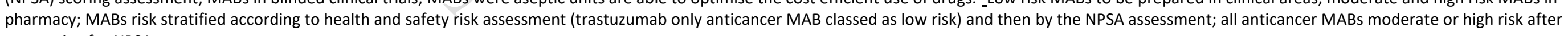
accounting for NPSA score 